\title{
A Quest for Repositioning: The Emerging Internationalization of Chinese Companies
}

\author{
Sten Söderman ${ }^{\mathrm{a}}$, Anders Jakobsson ${ }^{\mathrm{b}}$ and Luis Soler ${ }^{\mathrm{c}}$ \\ ${ }^{a}$ Stockholm University School of Business, Stockholm 106 91, Sweden. \\ E-mail: sod@fek.su.se \\ ${ }^{\mathrm{b}}$ Sveaskog AB, Stockholm 105 22, Sweden. \\ E-mail: anders.jakobsson@sveaskog.se \\ ${ }^{\mathrm{c} S a a b}$ Avitronics, Saab AB (publ.), Stockholm 164 84, Sweden. \\ E-mail: luis.soler@saabgroup.com
}

When the third wave of internationalization appears in the near future, how will Chinese firms, especially small- and medium-sized companies (SMEs), position their products strategically? The framework of this paper is composed of price/ volume segments and impacts on product strategy theory. The aim is to identify important drivers and focus areas for Chinese companies and measure what role these play in different segments. The survey is a quantitative study based on responses given in April 2006 by 102 Chinese EMBA students currently working, largely as managers, in the Shanghai region. The results indicate that Europe has potential to be a priority target market for Asian companies. Net flows, over time, illustrate how the respondents believe their companies are presently positioned and how they will be positioned in the 'future' (year 2010). These net flows indicate that some Chinese companies will reposition themselves strategically when internationalizing and that they will focus on other factors or drivers when doing so, compared to companies adapting the prevalent price leadership strategy. The results should be seen as indicative and as presenting a template for deeper research.

Asian Business \& Management (2008) 7, 115-142. doi:10.1057/palgrave.abm.9200247

Keywords: China; internationalization; repositioning; future; Europe and EMBA

\section{Introduction}

How can emerging market firms (EMFs) improve their export performance? The so-called emerging markets or transition economies and their relations with the mature market economies of Europe and North America are creating strong competitive and cooperative forces. Firms from emerging markets are internationalizing and becoming new multinational companies (MNCs). According to certain projections, relations between the EU and 
North America and Asia and South America will change drastically (Jansson, 2007a). For example, a projection made by Goldman Sachs in 2003 of how Brazil, Russia, India and China will grow up to 2050 shows exciting results (Wilson and Purushothaman, 2003). This development was previously noted by Kumar and McLeod (1981) and Lall et al. (1983). However, a developed country's perspective continues to dominate the literature (Zou and Stan, 1998).

Small- and medium-sized enterprises (SMEs) in China work under significantly different conditions compared to larger companies with global ambitions that, with few exceptions, have strong support from local authorities and government (Keister, 2000; Zeng and Williamson, 2003; Deng, 2004; Wu, 2005; Buckley et al., 2007).

We expect further internationalization, but how will it happen and what will be the key driver or drivers? By studying how companies have positioned themselves strategically (in a price/volume matrix), possible differences in the rated importance of different drivers depending on the strategic position a company claims to hold are illustrated. The essential drivers in different strategic positions will therefore be examined. By doing this, we aim to further Child and Rodrigues' (2005) conceptualization of Chinese companies' internationalization by looking at the impact of pricing and product positioning strategies.

Secondly, how companies believe themselves to be positioned in the price/ volume matrix today and in 2010 is studied, in order to detect any repositioning patterns over time. We have studied the responses of all companies as well as the results of SMEs in comparison to the other companies. Our study indicates that the results are valid for all Chinese companies and to a larger extent for SMEs.

\section{Theory and Four Propositions}

According to Jansson (2007b), we are about to experience 'The third wave of internationalization'. The first wave was the internationalization of big companies from Europe and North America, which took place from the end of the 19th century until the 1970s, a process that mainly involved market economies in Europe and North America. The second wave was that of companies from Japan and later South Korea. These companies emerged on the world market while Western companies simultaneously expanded into East Asia. The third wave involves companies from mature Western markets establishing themselves in China, India, Russia, and Central- and Eastern Europe (CEE), while companies from these countries are entering the world market and, in some cases, themselves becoming MNCs. This has been the 
result of the opening up of China and India to international markets as well as the integration of the CEE countries into the common market of the EU.

EMFs differ from MNCs as they usually do not have well-recognized global brands and lack resources and international market experience (Zhang and van den Bulcke, 1996; Hitt et al., 2000; Hoskisson et al., 2000; Newman, 2000; Steensma et al., 2005; Yiu et al., 2007). In China as well as other developing countries, this 'third wave' will be constituted by a massive internationalization of SMEs (Peng, 2001). The question, however, remains how these companies will position themselves when moving abroad. Will they all adopt the 'Economy Product Strategy', co-aligning with their local competitive advantage as indicated by Brouthers et al. (2000) and Brouthers and Xu (2002)?

Proposition 1: Chinese exporting companies have a different initial position compared to that of Western companies, starting their export activities under the first wave of internationalization.

People in Western countries today often associate Chinese products with fairly low technical content and sometimes poor-quality and a low-price 'Economy Product Strategy' (Brouthers et al., 2000). From a Western perspective, one might perceive that the only products successfully exported from China are those that are positioned in the low-price segment of their specific markets, while those that are not so placed fail to offer enough value for money to be successful in international markets. It seems that most internationalizing Chinese companies have approached the 'Cost Leadership Strategy' (Porter, 1985) when positioning themselves in a foreign market. Many Chinese exporters '... adopt the stereotype price leadership strategy due to corporate climate, factor costs and demand conditions in China' (Brouthers and $\mathrm{Xu}$, 2002: 659) and many firms believe that a low-price strategy is their main competitive advantage (Young et al., 1996). The pace of institutional changes and liberalization of industries is high and has in a rather short time turned China into the 'factory of the world' (Wilson and Purushothaman, 2003). Chinese companies seldom seem to seek a differentiation strategy by differentiating their products in terms of form, features, performance quality, conformance quality, durability, reliability, reparability and style. The pricing objective of most Chinese companies seems to be, at least from an outside perspective, maximizing market share, thus assuming that higher sales volumes lead to lower unit costs and higher long-run profits (Kotler and Keller, 2006) (Figure 1).

What are the drivers behind the internationalization of Chinese companies? There are proactive as well as reactive motives or intentions for going abroad (Albaum et al., 1994; Buckley et al., 2007; Yiu et al., 2007). Walters and Zhu (1995) explain the international marketing activities of Chinese exporters as an 


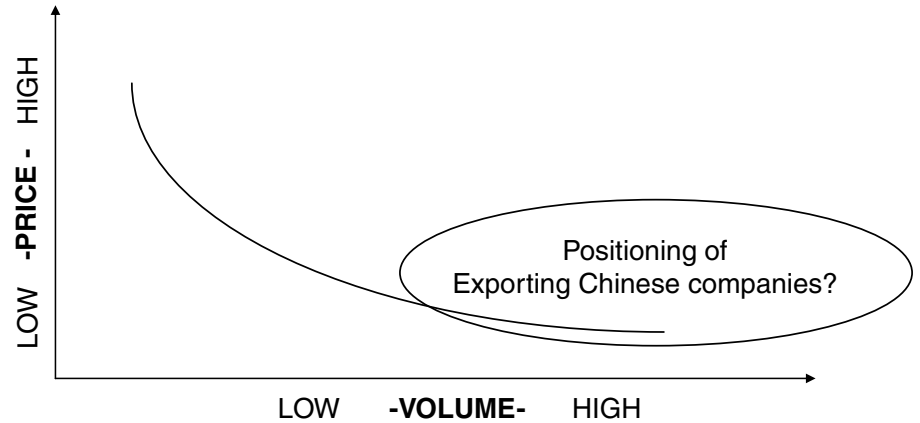

Figure 1 Starting position of exporting Chinese companies.

informal 'diaspora'. However, the better-known eclectic theory (Dunning, 1980) embraces the three major motives and forms of foreign involvement by enterprises; namely, export, direct investment and contractual resources transfer. Child and Rodrigues (2005) describe, in the notion of the 'latecomer perspective' (opposite to the 'first-mover advantage'), that many companies in China seek internationalization in order to gain assets that can help them address relative disadvantages. This is contrary to the assumption of mainstream theories that internationalization is driven by companies wishing to exploit ownership advantages (Dunning, 1980). Chinese companies, as explained by Child and Rodrigues, are therefore addressing 'complementarity' by seeking assets such as technology, brand knowledge, R\&D capabilities and internationally experienced management. Lecraw (1981) has examined the possible effects of competition on the profitability attained by MNCs. His data suggest that while rivalry among multinationals reduced their profitability, developing-country firms (less developed countries (LDCs), of which many were EMFs) did not actively compete with counterparts from industrialized nations (ie developed countries (DCs)). They generally operated in different fields. Thus, Lecraw concludes that these firms have limited countervailing power against firms from DCs.

The first group of companies, occupying position or segment 1 (see Figure 2), focus on a cost leadership strategy (Porter, 1985) by seeking efficiency in production, chasing cost reduction through all possible measures, securing volume through distribution channels and joint ventures, and by acting as original equipment manufacturers. Price erosion is slowed down by a high innovation ratio.

The second group (Figure 2, position 3) must concentrate on differentiation through market strength, product positioning and on securing a higher perceived value in the offered product or service. For the second group of companies, when offering products abroad, it is vital to offer enough perceived 


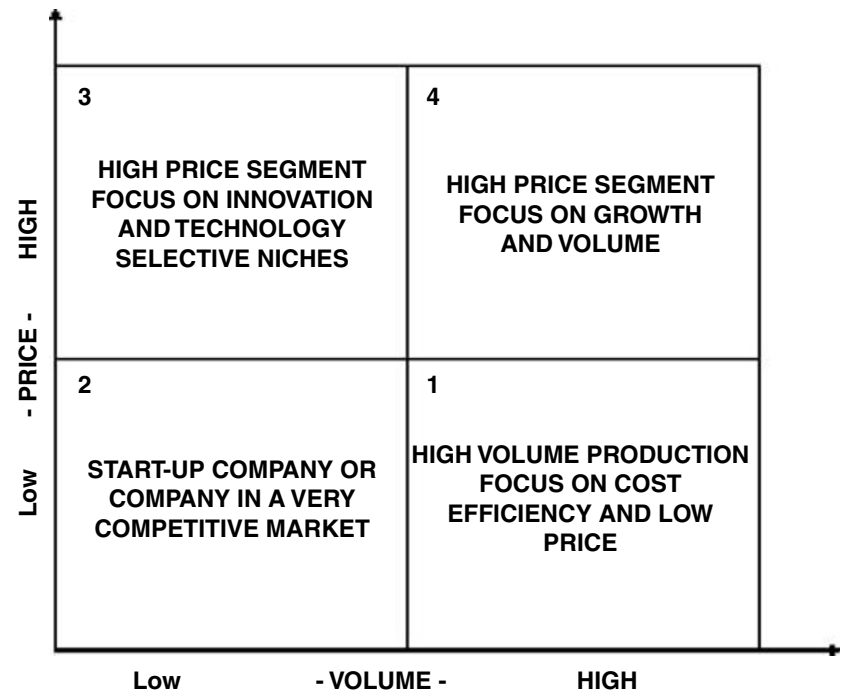

Figure 2 Price/volume matrix. Source: derived and modified by the authors from Porter (1985).

value for money in the high-price segment by securing the value of innovative products with high technological content (R\&D and technology) and a wellknown brand name. If they fail to succeed, they risk the dilemma of 'getting stuck in the middle' (Porter, 1985: 16) and slipping to position 2. They are neither sufficiently cost-efficient to compete on price, nor able to defend a higher price in the high-price segment (Figure 2, position 2). These companies will presumably run out of business sooner or later.

Many Chinese companies can be hypothesized to internationalize and reposition themselves from the low- to high-price segment as they either discover that their home market is not big enough in the high-price segment or as they realize that tough local competition will present a barrier to the large volumes and profits (Brouthers and $\mathrm{Xu}, 2002$ ) needed to survive in position 1 (Figure 2, position 1). Companies repositioning have come to the conclusion that they can reach equal or larger total profits in the high-price/low-volume segment than in the low-price segments with larger volumes. The higher price levels and thus potential for higher margins in Western countries become very attractive for companies either in the process of, or considering, strategic repositioning. A strategy of price leadership (defined as the lowest price) results in superior performance, according to Brouthers and $\mathrm{Xu}$ (2002). However, performance satisfaction increased when Chinese exporters used a branding product strategy.

Child and Rodrigues (2005) recognize the accomplishments of Western internationalization theories such as the Uppsala model, which introduces the 
concept of psychic distance, the Transaction Cost Model and the Born Global Model, and see their own theory as an extension of existing theory. Wells (1981) suggested that the special assets of developing-country firms follow from the peculiar nature of their home markets, conducive to innovations markedly dissimilar to those that take place in the industrial world. We are thus interested in the observation that Chinese firms are internationalizing in order to address competitive disadvantages. This becomes very important in comparison to, for example, the wish to explore one's own competitive advantages when internationalizing.

While Western internationalization theories describe the modes in which Western companies began internationalization, they also describe an internationalization based on willingness to exploit company- and country-specific strengths. For example, Swedish companies can be viewed to have started their internationalization from position 3 in the price/volume matrix (Figure 3) (Sölvell et al., 1991). Many developed good inventions and innovative products with a quite large technological content, which commanded and could justify a high price. This is in line with the Premium Product Strategy proposed by Brouthers et al. (2000). Their push for internationalization was driven by a desire to increase volume by accessing other markets. Initially, many Swedish

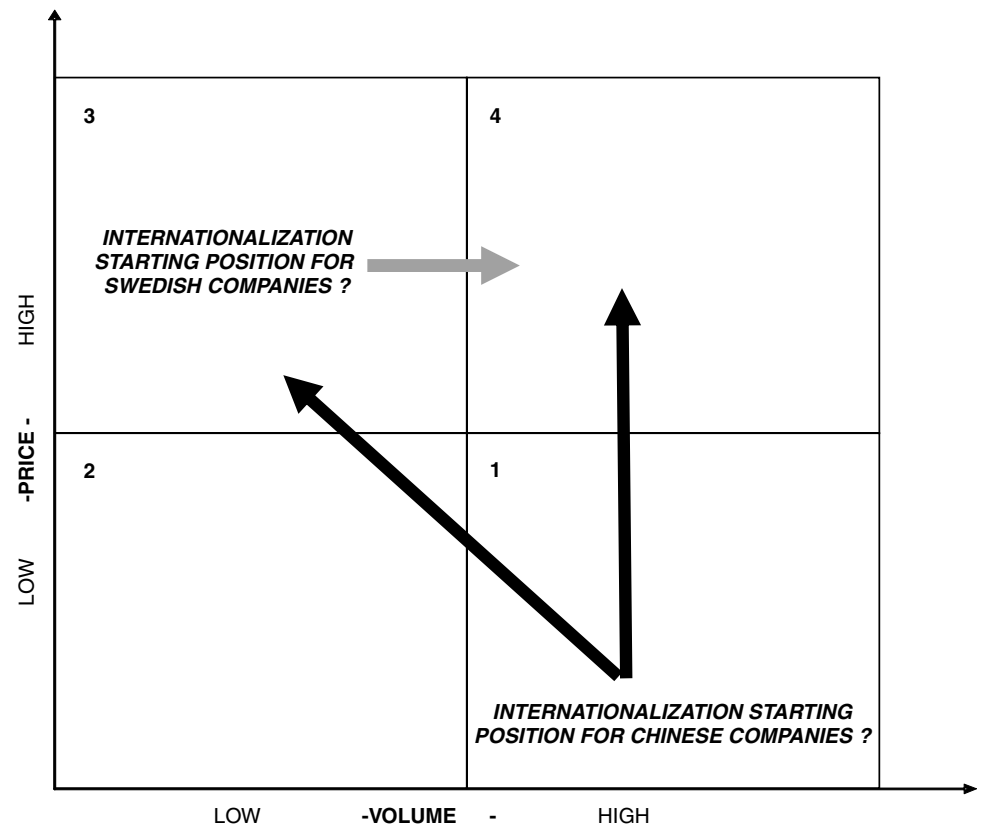

Figure 3 Starting position of Chinese and Swedish (Western) companies. 
companies aimed to stay in selected niche segments of their markets, where they could be sure to defend their premium price.

The internationalization of Chinese companies can, on the contrary, be explained by the latecomer perspective (Johanson and Vahlne, 1977; Child and Rodrigues, 2005; Jansson et al., 2007; Jansson, 2007b) or the Economy Product Strategy (Brouthers et al., 2000).

Proposition 2: There are 12 important export drivers derived from the literature.

By analysing frequently used literature on internationalization, for example, Hollensen (2004), the following theories and models were identified:

(1) Uppsala model ((Johanson and Wiedersheim-Paul, 1975; Johanson and Vahlne, 1990);

(2) Transaction Cost Analysis (TCA) model (Coase, 1937; Reid, 1983; Ghosal and Moran, 1996);

(3) Born Global model (Oviatt and McDougall, 1994; Knight and Cavusgil, 1996; Sharma and Blomstermo, 2003);

(4) Network model (Park, 1996; Johanson and Mattson, 1988);

(5) Child and Rodrigues', 2005 extension to the above;

(6) Cross-National Product Strategies (Brouthers et al., 2000; Brouthers and $\mathrm{Xu}, 2002)$

Of the above-mentioned models, the first four are perceived to represent mainstream internationalization theory. The contribution of (5) and (6) constitute a China-focused extension on models 1-4. But how can these six theories be used in future surveys? The intention was to come out with a 'net list' of 'key driving forces' (motives or factors; herein, key driving forces and drivers are used synonymously) that would be specifically relevant to either the current or future strategic positioning of Chinese companies. The idea and purpose was not to list and study all potential drivers for internationalization.

We identified a selected number of 'key driving forces'. Some derived from mainstream internationalization theory (Uppsala, TCA, Network and Born Global models) and others from Brouthers and $\mathrm{Xu}$, and Child and Rodrigues, these later drivers being more specific to the Chinese context.

The selected 'key driving forces' were:

- Gain international experience

- Explore own advantages on markets abroad

- Increase profit

- Increase sales volume

- Gain access to internationally experienced management or skilled human resources 
- Achieve international reputation and brand recognition

- Receive government support or finance

- Improve own-product development and innovation ratio

- Increase technology content of own products

- Improve customer service

- Improve quality of products

- Improve cost efficiency in production.

Child and Rodrigues (2005) talk in general terms about technology, but technology in this study is divided into three parts: technology content of one's own products, quality of products and efficiency in production. The 'product life cycle' theory proposes that firms innovate for their home market, generating skills and knowledge that are in some cases exportable abroad (ie an important driver in the first wave). Since managers are responsive to their home markets, the nature of a particular firm's advantage is influenced by the characteristics of the national market (Vernon, 1966).

Research results indicate that owners/founders of SMEs are much more inclined to internationalize, or start exporting, if they have prior international experience, skills or overall competence in doing business abroad (Manolova and Brush, 2002). International business activities for many companies, particularly high-technology companies, may be an integral part of that process (Hollensen, 2004).

The challenge facing most entrepreneurial companies in China is to establish and develop a viable, competitive and sustainable business, usually with limited resources and by adopting flexible, imaginative and innovative business practices (Bell, 2007). There is a tendency, specifically related to China, towards the increasing importance of SMEs in relation to large companies in internationalization. The explanation for this structural change is that such firms are under-represented in world markets, compared to their role in domestic markets (Jansson and Söderman, 2005) (Table 1).

Proposition 3: The 12 key driving forces can be allocated to and distributed between four strategic positions, based on their expected importance in securing competitive advantage in each position.

We earlier divided the presented price/volume graph into four squares and described each of these positions (Figure 2). Figure 4 shows the expected distribution of the key driving forces based on the authors' own experience. The questions formulated when putting the 'key driving forces' into the figure have been:

- What parameters or drivers are essential for companies in the specific square, in the price/volume graph? 
Table 1 The 12 key driving forces and references from literature

\begin{tabular}{|c|c|}
\hline Key driving force & Examples of literature \\
\hline 1 Get international experience & Johanson and Vahlne, 1977 \\
\hline $\begin{array}{l}2 \text { Get access to internationally experienced } \\
\text { management or skilled human resources }\end{array}$ & $\begin{array}{l}\text { Child and Rodrigues, 2005; Manolova and } \\
\text { Brush, } 2002\end{array}$ \\
\hline 3 Explore own advantage on markets abroad & Johanson and Vahlne, 1977; Dunning, 1980 \\
\hline 4 Increased profits & $\begin{array}{l}\text { Johanson and Vahlne, 1977; Brouthers and Xu, } \\
\text { 2002; Kotler and Keller, 2006; Redding, } 2006\end{array}$ \\
\hline 5 Improve customer service & Child and Rodrigues, 2005 \\
\hline 6 Increase sales volume & Brouthers et al., 2000; Kotler and Keller, 2006 \\
\hline $\begin{array}{l}7 \text { Achieve international reputation and } \\
\text { brand recognition }\end{array}$ & $\begin{array}{l}\text { Brouthers and } \mathrm{Xu}, 2002 \text {; Child and Rodrigues, } \\
2005\end{array}$ \\
\hline 8 Government support or finance & Child and Rodrigues, 2005; Dolles, 2006 \\
\hline $\begin{array}{l}9 \text { Improve own product development } \\
\text { and innovation ratio }\end{array}$ & $\begin{array}{l}\text { Vernon, 1966; Brouthers et al., 2000; Child and } \\
\text { Rodrigues, 2005; Bell, } 2007\end{array}$ \\
\hline 10 Improve cost efficiency in production & $\begin{array}{l}\text { Wells, 1981; Brouthers and Xu, 2002; Child and } \\
\text { Rodrigues, 2005; Bell, } 2007\end{array}$ \\
\hline $\begin{array}{l}11 \text { Increase technology content of own } \\
\text { products }\end{array}$ & Wells, 1981; Child and Rodrigues, 2005 \\
\hline 12 Improve quality of products & $\begin{array}{l}\text { Brouthers et al., 2000; Brouthers and } \mathrm{Xu}, 2002 \\
\text { Child and Rodrigues, } 2005\end{array}$ \\
\hline
\end{tabular}

- What drivers are specifically important in each position?

- How much would expected distribution vary compared to a rated distribution?

- Would there be any unexpected distributions?

The authors assumed that no companies, in the long run, would want to stay in position 2 . This is an area for a new company on the market aiming for position 1 or for a company initially in position 1, but being pushed into position 2 by tough competition and subsequently trying to reposition to square 3. Position 1 corresponds to the Economy Product Strategy (Brouthers et al., 2000). A company trying to differentiate by offering higher value for money in position 1 (eg, through higher quality, as offered by Japanese companies) would adopt the Superior Value Product Strategy in position 1. Positions 3 and 4 correspond to the Brouthers et al's. Premium Product Strategy. These two represent differentiation strategies where differentiation factors are needed in order to defend a premium price. We have assumed that prices have been set so that perceived value for money is the same in all four segments.

Proposition 4: Most Chinese companies will stay in position 1 and enjoy the benefits of their country-specific advantages, but a number will reposition by leaving position 1 and aiming for position 3 , the high-price/low-volume segment. 


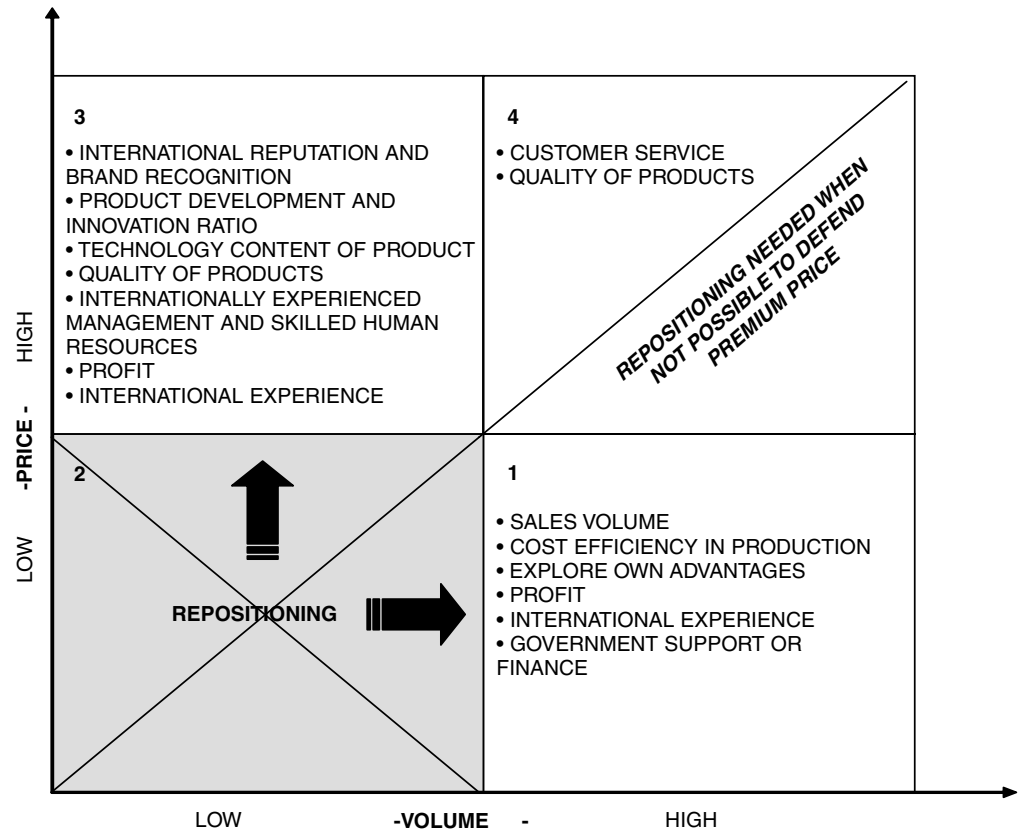

Figure 4 Expected distribution of our 12 drivers in the price/volume matrix.

Some companies will reposition to the high-price/low-volume segment with the view of potentially increasing their total profit in these high-price segments. In doing so, they leave the strategic advantage of their home-country conditions (Brouthers et al., 2000). Chinese companies can also benefit from their lower costs in the high-price/high-value segments. They have a cost advantage compared to Western companies in terms of (but not limited to) lower hourly rates in R\&D and product development, lower capital costs and an overall lower cost structure. This gives them a potential for higher margins in high-price segments compared with Western companies. However, when targeting Western countries, part of this cost advantage is sacrificed because of a need to invest in securing assets that they lack domestically and that are fundamental in the high-price/high-value segments. Such assets are, for example, branding, part of $\mathrm{R} \& \mathrm{D}$, internationally experienced management and local support, which can never be neglected when aiming for the highprice/high-value segments.

In the long term, many Chinese companies will need to reposition from segment 1 to segment 3, as price leadership does not provide a basis for sustainable competitive advantage (Porter, 1985; Liu and Song, 1997; Brouthers and $\mathrm{Xu}, 2002)$. This is apparent, as China's labour cost advantage is 
vanishing as other Asian countries become significantly more cost-competitive and as fierce domestic competition in China continues to slash profits.

\section{Data and Methodology}

Collecting primary data from interviews has been the best source of information, largely because secondary data supporting company research in China is still far from sufficient, and research on SMEs, being mainly qualitative, is based on rough estimations or focuses on particular case studies of selected regions. Problems with data concerning companies are mainly derived from statistically fragmented work according to functional or jurisdictional criteria, inter alia leading to the neglect of small firms. There also seem to be serious distortions of data through widespread misreporting and falsification.

The research questions were operationalized in a questionnaire that was validated in Stockholm. Seven different Chinese business people were interviewed and asked to fill in the papers, which were modified several times.

As mentioned before, a group of executive MBA students at Shanghai University were selected as a sample for the study, for several reasons. Choosing an executive MBA group as a sample ensured the following: (1) high response rate, (2) representative sample of Chinese managers (as EMBA students need to have several years of work experience), (3) the group would most likely understand a questionnaire in English, (4) the group will most likely become, if not already, senior managers in Chinese companies, (5) the group probably has good insight into their companies' strategic direction, such as internationalization.

The survey was conducted on 102 respondents. One of the authors explained the study for $1 \mathrm{~h}$ before the questionnaires (see Appendix A) were to be filled in. The respondents took more than one full hour to answer the questions and they were asked to classify their current and future business in the price/volume matrix. The data were collected in April 2006 and then immediately assembled in a data matrix. The respondent's characteristics are briefly explained in Appendix B. The data material were processed in an Excel program, which was summarized in order to enable a thorough analysis.

\section{Findings}

We have in our study identified four different potential product strategies. By product strategies, we mean strategies relating to how a product is positioned compared to competing products. By positioning we refer to the inclusive process, starting with the analysis of a potential customer segment to actually designing the product to meet that specific customer segment in terms of 
specifications, service and support, performance, brand awareness and pricing. Our basic assumption has been that if the product has already been developed and targeted at a specific customer segment, it is not possible or not easy to reposition the product to another customer segment in the price/volume matrix. Our main focus has been industrial companies and industrial products.

Figure 5 shows the actual distribution of the drivers rated as most important in each specific segment. These drivers are those scoring the highest value in each specific segment and have all been ranked above average in these segments. Figure 5 should be compared to Figure 4 (the expected distribution). Even though the actual distribution of the most important drivers turned out to be close to the results we had expected, there are some interesting differences. We had not anticipated that drivers such as quality, service and support, and R\&D and innovation would have been considered as important in segment 1 . This is probably the result of the extremely high competition in segment 1. In segment 1, the 'Rational Producer' (Chinese companies' prevalent product strategy), the companies' focus is on securing market share and volume. Factors such as cost efficiency in production, innovation, service and quality are essential in order to keep customer loyalty and defend threatened profits. Quality is in focus in all four segments.

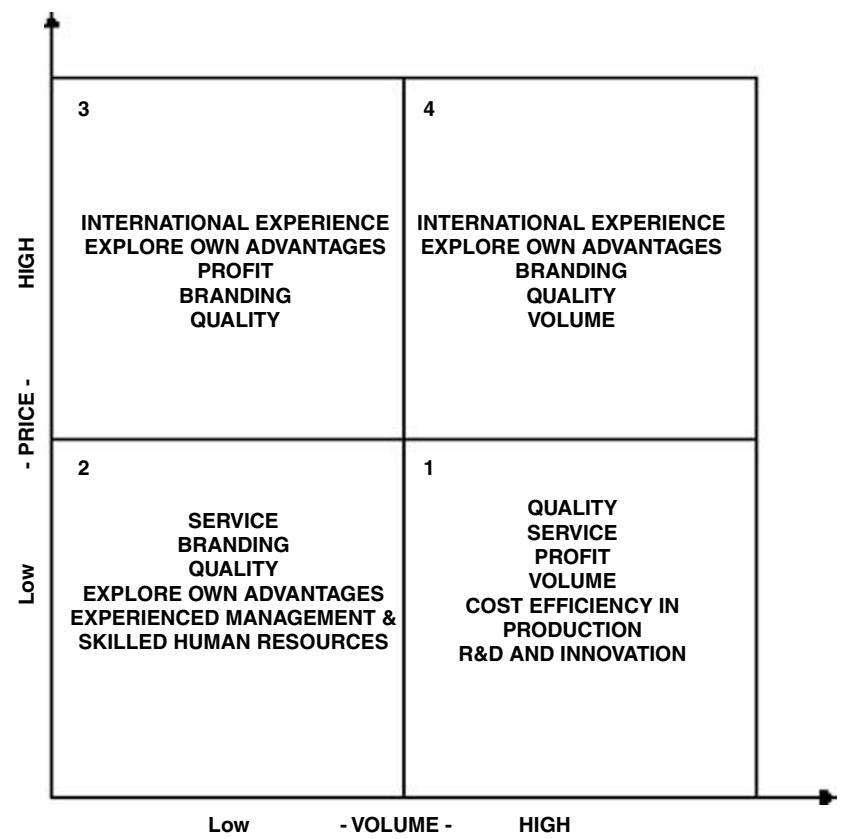

Figure 5 Actual distribution of drivers. 
Companies in or aiming for segment 3 focus more on branding, international experience (also reported by Hitt et al., 2000; Hoskisson et al., 2000; Newman, 2000; Steensma et al., 2005) and on capitalizing on their own advantages. Own advantages could be lower costs that need not necessarily be transferred into lower prices, but higher profits.

Here we come to a different conclusion than Brouthers and Xu (2002), where our findings indicate that branding is an important differentiating factor in the two high-price segments. Brouthers and Xu suggest that branding is only used by Chinese companies when targeting LDCs, not DCs.

One of the remaining open questions from this study is how to explain the relatively high result received in general (Figure 6). The reason behind this is difficult to explain and requires further investigation. It is clear that the respondents have perceived all the drivers except one to be very important (see below), but even the small deviation from this high rating is striking. We also examined if there were any possible patterns in the responses that seemed illogical, but none were found. Eight of the respondents rated all 12 drivers as very important, but even if the study discarded those responses as inconsistent, it would not significantly affect the average result.

The perceived value of the 12 drivers is analysed on the total sample of the population (102) and also on a number of sub-clusters. The perceived value will be presented for the total average, as well as for SMEs only. (As per

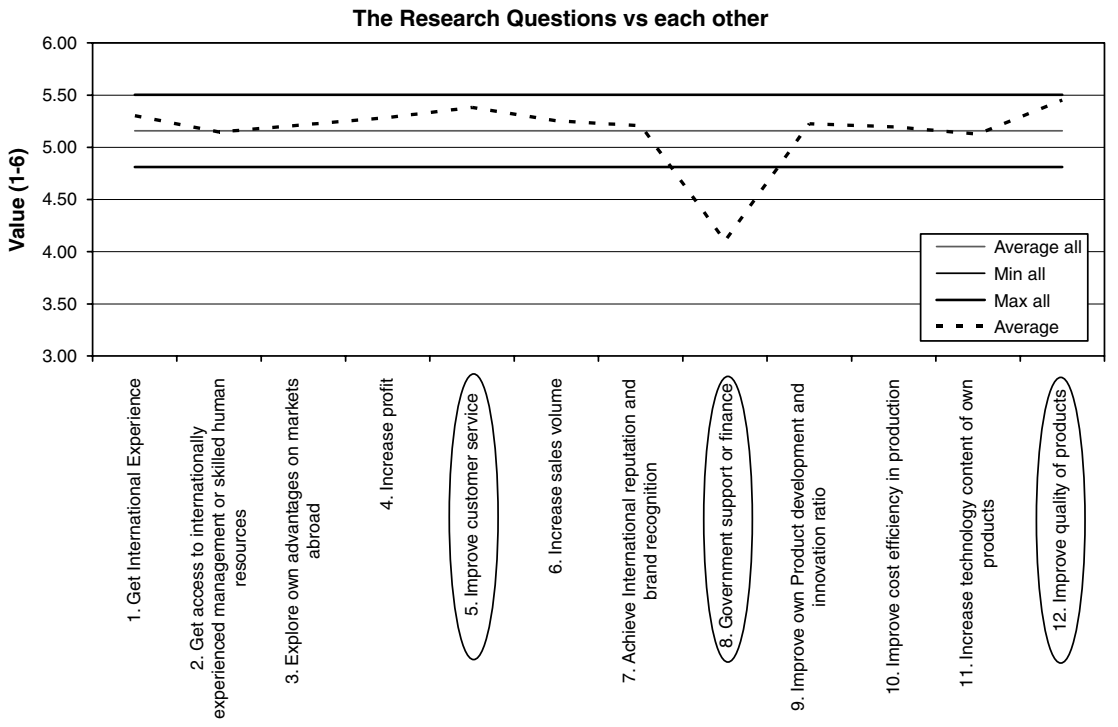

Drivers

Figure 6 Twelve drivers for Chinese companies' internationalization. 
Recommendation 96/280/EC from 1 January 2005, stating companies with less than 250 employees correspond to almost 47 per cent of the examined sample.) Contrary to Child and Rodrigues (2005), the survey shows that 'government support and finance' is less important than the other drivers. A similar result is reported by Dolles (2006), who claims that there is no doubt about the entrepreneurial distrust of the central government and further notes that this driver has a drastically different response result than the other drivers.

The survey also shows the existence of repositioning flows. As anticipated, most companies want to avoid segment 2. We can also see that many companies want to reposition to segments 3 and 4 . It can also be seen that some companies in segment 4 want to position themselves in segment 3 . That is, those in segment 4 , when chasing large sales volumes, have been unsuccessful in selecting profitable business or they have not reached the cost advantages they believed larger volume would provide.

As can be seen in the 6-graded scale in Figure 6, the survey shows that all the studied drivers are important to the respondents, except No. 8: 'government support and finance'. This question, rated 4.1 on average, clearly falls outside the confidence interval of the average result of all the drivers. Even though one of the questions (No. 8) clearly differs from the others by being rated lower, it is still rated as important. The reason why this driver seems to be less important than the others requires further investigation. There is, however, no doubt that the respondents have rated this driver lower than the others.

The overall average is 5.2 and we notice that the respondents have rated the questions in the questionnaire relatively high, in general. The evidence is that all the drivers except one are of great importance. Thereby, the conclusion is that the drivers derived from the Child and Rodrigues (2005) extension are as important as the drivers derived from mainstream internationalization theory, except 'the importance of government support and finance'.

Also noted is the relatively high importance attached to the drivers 'improve quality of products' (average 5.5) and 'improve customer service' (average 5.4). The relatively high importance of these two drivers was somewhat unexpected, as they are not prevalent in the Child and Rodrigues theory.

The starting position for Chinese companies is illustrated in our survey when internationalizing, as shown in segment 1 (58 per cent), which confirms initial assumptions in Proposition 1.

Two drivers that have proven to be among the most important are 'quality of own products' and 'customer service'. These are mentioned by Child and Rodrigues, but not stressed as overly important.

SMEs correspond to almost 47 per cent of the examined sample. Figure 7 indicates that even though the results are valid for all companies, it seems that the results are even more valid for SMEs. 


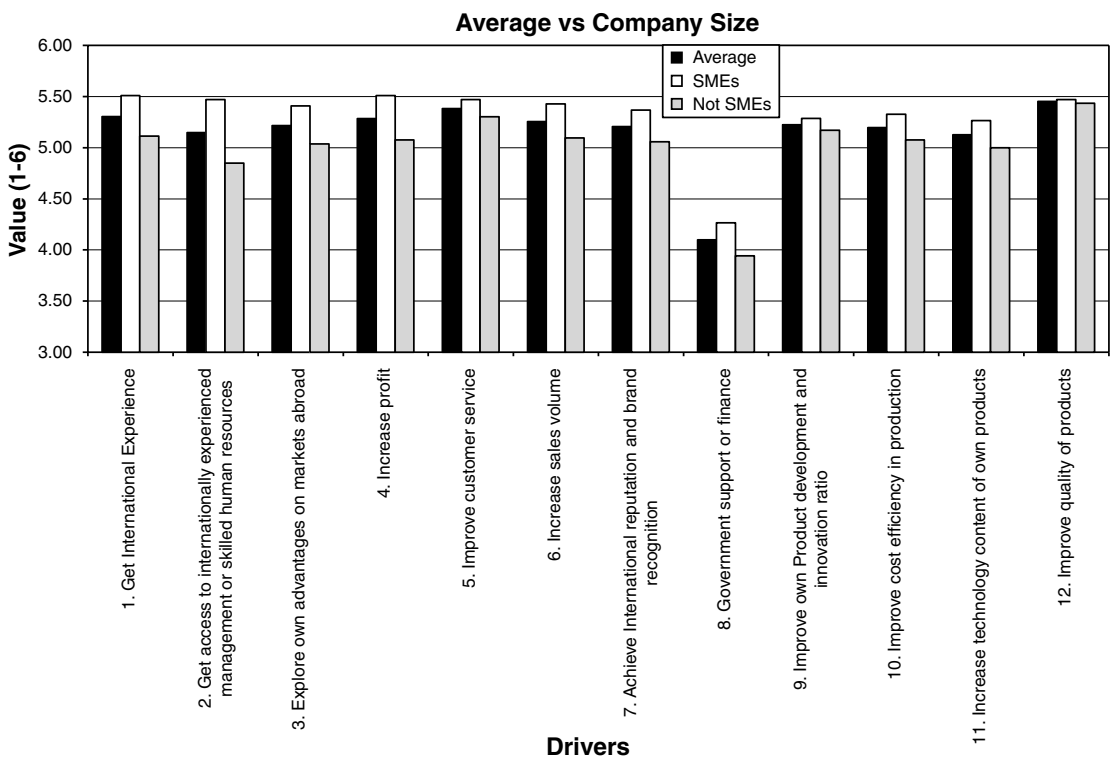

Figure 7 Importance of internationalization drivers for SMEs.

Figure 8 shows that the most attractive market for most companies is Asia, followed by Europe and North America. This indicates Europe could be the most attractive market outside Asia. A possible reason for this is that Europe is perceived as less competitive than North America. The percentage figures show how many of the respondents have stated a market to be attractive.

Figure 9 shows the net flows, over time, between different segments. It shows the net flow between how the respondents believe their companies to be positioned today and how they believe their companies will be positioned in the 'future' (ie year 2010).

We expected a certain repositioning of companies from position 1 to 3 and 4 (see also Figure 3). We also expected that a lot of companies would be having difficulties in position 2 and therefore desired repositioning elsewhere. The conclusion of the above figure is that the expected net flow is confirmed. Position 3 has a net flow from all the other squares. The relative number of firms in the field is increasing from 13 to 30 per cent. Position 4 might show that some companies, when having difficulties in this area, chose to focus on niche positions rather than volume in order to defend their profitability. Most of the companies try, as expected, to avoid staying in position 2 .

The final conclusion is that when internationalizing, the starting position of many Chinese companies is in segment or position 1, while many try to reposition to segments 3 and 4, as anticipated in Figure 4. It also seems to 


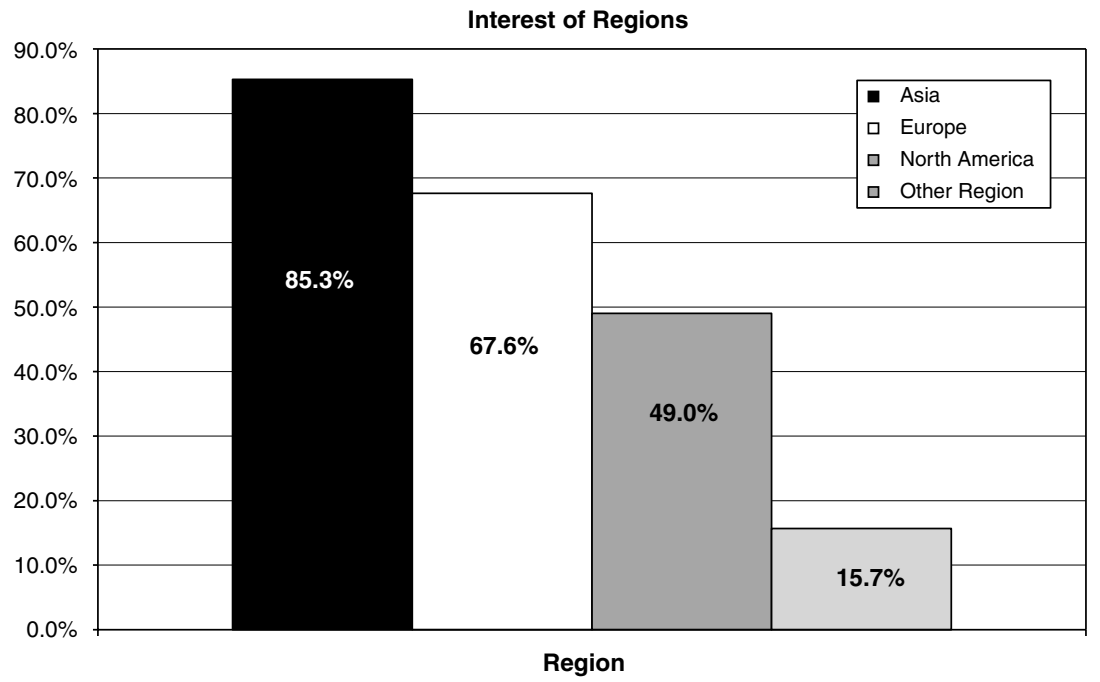

Figure 8 Attractiveness of different regions for Chinese companies.

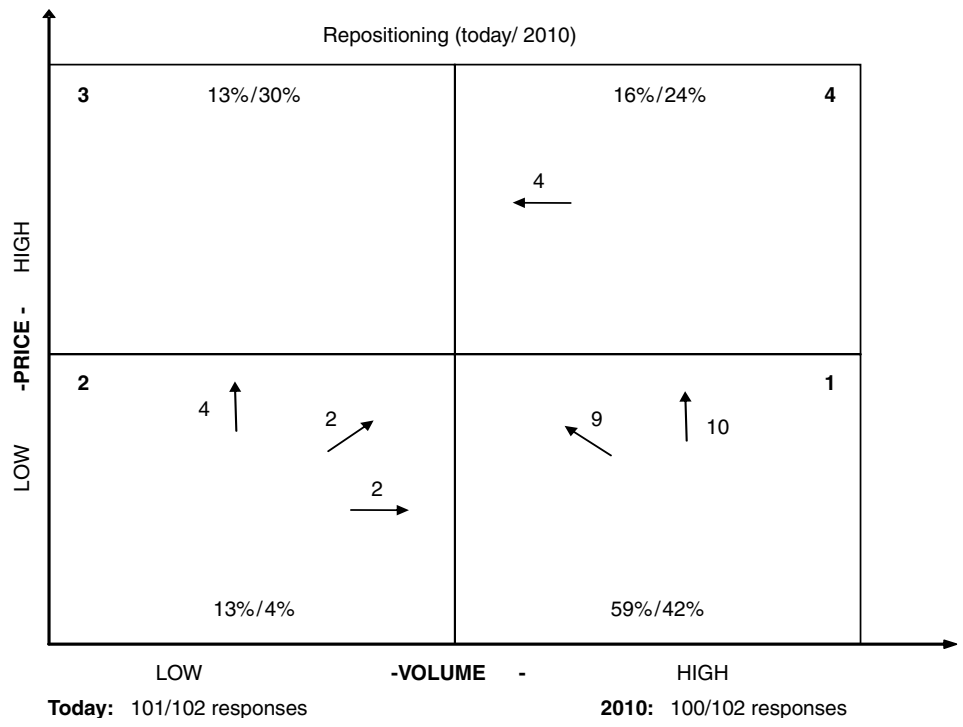

Figure 9 Net flows between segments over time.

confirm the assumption (Figure 9) that most companies in position 2 have difficulties defending their cost focus and therefore try to reposition themselves into other areas. 
Finally, this suggests that, as mentioned above:

- Companies find Europe an attractive market outside Asia,

- SMEs rate the importance of the drivers higher than that of the overall sample group;

- There are repositioning flows over time to positions 3 and 4 (Proposition 4).

It can be argued that it is very likely that many (though not the majority) of Chinese SMEs will reposition themselves strategically into positions 3 and 4 when heading for internationalization.

\section{Discussion}

The aim is to measure possible deviations or a lack of deviations within this reference group without drawing lengthy conclusions on how applicable this would be to all companies in China. We are more interested in showing that there are differences between companies, depending on their price positioning strategies. Possible repositioning flows are described as the first sign of a more diversified picture of Chinese companies expanding into new geographic markets in the future. Not all companies are, or will be, competing with low cost and low price. Numerous companies will be competing with technologically advanced products and recognized brand names in the high-price segments of their specific markets.

One striking result is how strong competition in segment 1 seems to have raised the importance of 'innovation ratio', 'product quality' and 'customer service'. In order to avoid price erosion and to keep competition away, companies need to focus on these aspects simultaneously as well as anticipated issues such as 'sales volume' and 'cost efficiency in production'.

The late development thesis, which can be applied to China, formerly comprised countries such as South Korea, Taiwan, Hong Kong, Singapore and now countries in South East Asia, gives a potential explanatory contribution. The latecomer firms from these countries (EMFs) did not start from a position of strength, but from a position where they were seeking access to knowledge in the technological and business mainstream. Even though these firms had some initial competitive advantages, such as low labour costs, these became less crucial as they moved into more sophisticated markets with higher-value products. An interesting aspect of the latecomer perspective is that it attracts investment as a means to address competitive disadvantages, which helps companies that are not initially competitive on the world market to close the gap by acquiring appropriate assets and resources (also supported by Herrman-Pillath et al., 2002; Boisot, 2004) (Table 2). 
Table 2 The four propositions and their conclusions

Propositions
Proposition 1: Chinese
exporting companies have
a different initial position
compared to that of Western
companies starting their
export activities under the
first wave of
internationalization

Proposition 2: There are 12 important export drivers derived from the literature

Proposition 3: The 12 key driving forces can be allocated and distributed to four strategic positions based on their expected importance in securing competitive advantage in each position.

Proposition 4: Most Chinese companies will stay in position 1 and enjoy the benefits of their countryspecific advantages, but a number will reposition by leaving position 1 and aiming for position 3, the high-price/ low-volume segment.
Conclusion

Chinese companies are starting from the low-price/high-volume product position that is equivalent to the economy product strategy mentioned by Brouthers et al. (2000). This is due to historic and country-specific reasons striving for cost leadership and aims to maximise market shares. This is in contrast to Western companies, which have originally applied the high-price/ low-volume strategy that is similar to the premium product strategy.

The 12 drivers are: get international experience, get access to internationally experienced management or human resources, explore own advantages on markets abroad, increase profit, improve customer service, increase sales volume, achieve international reputation and brand recognition, get government support and finance, improve own product development and innovation ratio, improve cost-efficiency in production, increase technology content on own products and finally improve quality of products. Even though all are considered very important, one is rated less important than the others: 'get government support and finance', which is normally more accessible for larger companies, not SMEs. Companies aiming for the high-volume/low-price position put more focus on drivers like efficiency in production, innovation, service and volume in order to defend or achieve their strategic position, while companies aiming for the high-price/low-volume position focus more on getting international experience, exploring own advantages and branding. Quality seems to be a prioritized driver for all Chinese companies.

When Chinese companies are repositioning for the premium price area, they are focused on addressing competitive disadvantages they have compared to DC companies. At the same time they are trying to explore their own advantages. Competitive disadvantages they are addressing when repositioning are: no brand recognition and a lack of international experience while they as other Chinese companies in other segments continue to focus on quality, and profit. Our conclusion goes against Brouthers and Xu's conclusion that Chinese companies should not apply branding when targeting DC markets as performance satisfaction is higher when applying a non-branding strategy. We can show that branding is less important for companies focusing on the price leadership product strategy, but for those companies aiming for the premium product strategy, branding and international reputation is considered very important. This conclusion supports Child and Rodrigues' conclusion that branding is a focus area for Chinese companies aiming for internationalization. Chinese companies repositioning to the premium product area when entering Europe will drastically change the existential conditions of many Western companies. 


\section{Managerial Implication}

The perspectives of the Chinese general manager or managing team within enterprises have been analysed, as well as the problems and opportunities they might encounter when attempting or planning to internationalize towards a new market, like Europe. One of the aims of the study was to show the importance of different drivers in different strategic positions. This has been confirmed, as knowledge of the drivers behind internationalization reveals not only the starting position of a company but also, importantly, the strategic direction they envisage for the future. There is varying emphasis on different aspects, depending on the strategic positioning of the company and the area they are positioned in. This result has been achieved by having the respondents show the positioning of their company presently and as anticipated in the year 2010. It is clear that the focus on different aspects, or drivers, changes over time. These priorities are summarized in Figure 9.

Results indicate that Europe could be a target market, and from a Chinese perspective, could be seen as an interesting market with a potential for higher margins, higher price levels and a more mature market for branding, technology, etc. At the same time, Europe does not represent a neighbouring or 'home' market, as do markets in South-East Asia.

\section{Limitations and Additional Suggestions for Future Research}

The survey is a quantitative study based on the responses of Chinese EMBA students in the Shanghai region in 2006, with a total of 102 respondents. Given the small sample size, this initial research has been of an exploratory nature. A future survey based on a larger quantity of Chinese companies selected from several regions in China is recommended in combination with qualitative interviews and case studies, which would possibly deepen knowledge of the drivers behind Chinese SMEs' internationalization. A 'country of origin' approach should be balanced with the type of industry, such as business to business vs. business to consumer. A larger study would further deepen knowledge of repositioning flows. One starting point might be Redding (2006), who mentions that migration from China in the late19th century pays tribute not only to the Chinese capacity for network capitalism and business discipline, but also to China's 'proven' entrepreneurship.

If subsequent research is conducted within this subject, it should attempt to further understand the drivers behind internationalization within the different positions. What are the factors behind the companies in the different segments, and in some cases, why are there changing priorities over such a short time? Is it the extremely competitive market they are working in? Or does it reflect the rapid change and development they have been going through during recent 
years? Why are the majority of the companies reluctant to establish themselves in position 2, due to cost focus or other factors? Is this something unique for China, due to extreme competition and difficulty surviving in this position, and does this represent a genuine threat to survival?

\section{Conclusions}

We can acknowledge that the Uppsala model concept of psychic distance by preference to start exportation to neighbouring countries seems to apply also for Chinese companies, as they cite Asia as the most attractive market. We believe there is validity in Jansson's (2007b) prediction of a third wave of internationalization. As competition increases in their domestic market, great numbers of Chinese companies will consider Western markets attractive for their products and services. The near future will bear witness to the targeting of Western countries and the subsequent internationalization of a number of these companies, which, regardless of their success or failure, will drastically change the existential conditions for Western companies.

\section{Acknowledgements}

We thank Martin Hemmert and the anonymous referee for their critical comments on two earlier drafts of this article.

\section{References}

Albaum, G., Strandskov, J., Duerr, E. and Dowd, L. (1994) International Marketing and Export Management 2 nd edn, Reading: Addison Wesley.

Bell, J. (2007) 'China's new mantra: innovate not imitate', Far Eastern Economic Review 170(2): 37-40.

Boisot, M. (2004) 'Notes on the internationalisation of Chinese firms', Unpublished Paper, Open University of Catalonia, Barcelona, Spain.

Brouthers, L.E., Werner, S. and Matulich, E. (2000) 'The influence of triad nations' environments on price-quality product strategies and MNC performance', Journal of International Business Studies 31(1): 39-62.

Brouthers, L.E. and Xu, K. (2002) 'Product stereotypes, strategy and performance satisfaction: the cases of Chinese exporters', Journal of International Business Studies 33(4): 657-677.

Buckley, P.J., Clegg, L.J., Cross, A.R., Liu, X., Voss, H. and Zheng, P. (2007) 'The determinants of Chinese outward foreign direct investment', Journal of International Business Studies 38(4): 499-518.

Child, J and Rodrigues, B.S. (2005) 'The internationalisation of Chinese firms: a case for theoretical extension?' Management and Organisation Review 1(3): 381-410.

Coase, R.H. (1937) 'The nature of the firm', Economica 4(16): 386-405.

Deng, P. (2004) 'Outward investment by Chinese MNCs: motivations and implications', Business Horizons 47: 8-16. 
Dolles, H. (2006) 'The Changing Environment for Entrepreneurship Development: Private Business in the People's Republic of China', in S. Soderman (ed.) Emerging Multiplicity, Basingstoke: Palgrave Macmillan.

Dunning, J.H. (1980) 'Toward an eclectic theory of international production: some empirical tests', Journal of International Business Studies 11(1): 9-31.

Ghosal, S. and Moran, P. (1996) 'Bad for practice: a critique of transaction cost theory', Academy of Management Review 21(1): 13-47.

Herrman-Pillath, C., Li, K. and Pan, J. (2002) 'Development challenges to small and medium-scale industrial enterprises in the people's republic of China'. Duisburg Working Papers on East Asian Economic Studies, Gerhard Mercator Universität, Duisberg.

Hitt, M.A., Levitas, E., Arregle, J. and Borza, A. (2000) 'Partner selection in emerging and developed markets contexts: resource-based and organisational learning perspectives', Academy of Management Journal 43(3): 449-467.

Hollensen, S. (2004) Global Marketing; A Decision-Oriented Approach, 3rd edn. London: PrenticeHall.

Hoskisson, R.E., Eden, L., Lau, C.M. and Wright, M. (2000) 'Strategy in emerging economies', Academy of Management Journal 43(3): 249-267.

Jansson, H. (2007a) International Business Strategy in Emerging Country Markets. The Institutional Network Approach, Cheltenham: Edward Elgar.

Jansson, H. (2007b) International Business Marketing in Emerging Country Markets. The Third Wave of Internationalisation of Firms, Cheltenham: Edward Elgar.

Jansson, H. and Söderman, S. (2005) 'The third wave of internationalisation: small- and mediumsized enterprises from China', Stockholm University School of Business (Proposal to SAAPS), Stockholm.

Jansson, H., Söderman, S. and Zhao, X. (2007) Internationalisation of medium-sized enterprises from China: the take-off process Working paper, Stockholm University School of Business, Stockholm.

Johanson, J. and Mattson, L-G. (1988) 'Internationalisation in Industrial Systems', in N. Hood and J.-E.Vahlne (eds.) Strategies in Global Competition, Beckenham: Croom Helm, pp. 287-314.

Johanson, J. and Vahlne, J-E. (1977) 'The internationalisation process of the firm: a model of knowledge development and increasing foreign market commitment', Journal of International Business Studies 8(1): 11-24.

Johanson, J. and Vahlne, J-E. (1990) 'The mechanism of internationalization', International Marketing Review 7(4): 11-24.

Johanson, J. and Wiedersheim-Paul, F. (1975) 'The internationalisation of the firm: four Swedish cases', Journal of Management Studies 12(3): 305-322.

Keister, L.A. (2000) Chinese Business Groups. The Structure and Impact of Inter-Firm Relations During Economic Development, Oxford: Oxford University Press.

Knight, G. and Cavusgil, S.T. (1996) 'The born global firm: a challenge to traditional internationalisation theory', Advances in International Marketing 8: 11-26.

Kotler, P. and Keller, K. (2006) Marketing Management, London: Pearson Prentice-Hall.

Kumar, K. and McLeod, M.G. (eds) (1981) Multinationals from Developing Countries, Toronto: Lexington.

Lall, S., Chen, E., Katz, J., Kosacoff., B. and Villela, A. (1983) Multinationals from the Third World, Chichester: John Wiley.

Lecraw, D.J. (1981) 'Internationalisation of Firms From LDCs: Evidence from the ASEAN Region', in K. Kumar and M.G. McLeod (eds.) Multinationals from Developing Countries, Toronto: Lexington.

Liu, X. and Song, H. (1997) 'China and the multinationals - a winning combination', Long Range Planning 30(1): 74-83.

Manolova, T.S. and Brush, C.G. (2002) 'Internationalisation of small firms - personal factors revisited', International Small Business Journal 20(1): 9-31. 
Newman, K.L. (2000) 'Organisational transformation during institutional upheaval', Academy of Management Review 25(3): 602-619.

Oviatt, B. and McDougall, P. (1994) 'Towards a theory of international new ventures', Journal of International Business Studies 25(1): 45-64.

Park, S.H. (1996) 'Managing an inter-organisational network: a framework of the institutional mechanism for network control', Organisational Studies 17(5): 795-824.

Peng, M.W. (2001) 'How entrepreneurs create wealth in transition economies', Academy of Management Executive 15(1): 95-110.

Porter, M.E. (1985) Competitive Advantage: Creating and Sustaining Superior Performance, New York: Free Press.

Redding, G. (2006) 'Asia and its actors, their Logics and the Challenges', in S. Soderman (ed.) Emerging Multiplicity, Basingstoke: PalgraveMacmillan.

Reid, S.D. (1983) 'Firm internationalisation, transaction costs and strategic choice', International Marketing Review 1(2): 44-57.

Sharma, D.D. and Blomstermo, A. (2003) 'The internationalisation process of born globals: a network view', International Business Review 12: 739-753.

Steensma, H.K., Stevens, J.M. and Harrison, D.A. (2005) 'Symbolic or substantive document? The influence of ethics codes on financial executives' decisions', Strategic Management Journal 26: $181-195$.

Sölvell, Ö., Zander, I. and Porter, M.E. (1991) Advantage Sweden, Stockholm: Norstedt.

Vernon, R. (1966) 'International investment and international trade in the product cycle', Quarterly Journal of Economics 8: 190-207.

Walters, P.G.P. and Zhu, M. (1995) 'International marketing in Chinese enterprises: some evidence from the PRC', Management International Review 35(3): 265-280.

Wells Jr, L.T. (1981) 'Foreign Investors from the Third World', in K. Kumar and M.G. McLeod (eds.) Multinationals from Developing Countries, Toronto: Lexington.

Wilson, D. and Purushothaman, R. (2003) 'Dreaming with BRICs: the path to 2050', Global Economics Paper No.99, Goldman Sachs (http://www.gs.com).

Wu, F. (2005) 'The globalisation of corporate China', National Bureau of Asian Research 16(3): 1-29.

Yiu, D.W., Lau, C-M. and Bruton, G.D. (2007) 'International venturing by emerging economy firms: the effect of firm capabilities, home country networks, and corporate entrepreneurship', Journal of International Business Studies 38: 519-540.

Young, S., Hung, C-H. and McDermott, M. (1996) 'Internationalisation and competitive catch-up processes: case study evidence on Chinese multinational enterprises', Management International Review 36(4): 295-314.

Zeng, M. and Williamson, P. (2003) 'The hidden dragons', Harvard Business Review 81(10): 92-99.

Zhang, H.Y. and van den Bulcke, D. (1996) 'International Management Strategies of Chinese Multinational Firms', in J. Child and Y. Lu (eds.) Management Issues in China: International Enterprises, London: Routledge, pp. 141-164.

Zou, S. and Stan, S. (1998) 'The determinants of export performance: a review of the empirical literature between 1987 and 1997', International Marketing Review 15(5): 333-356. 


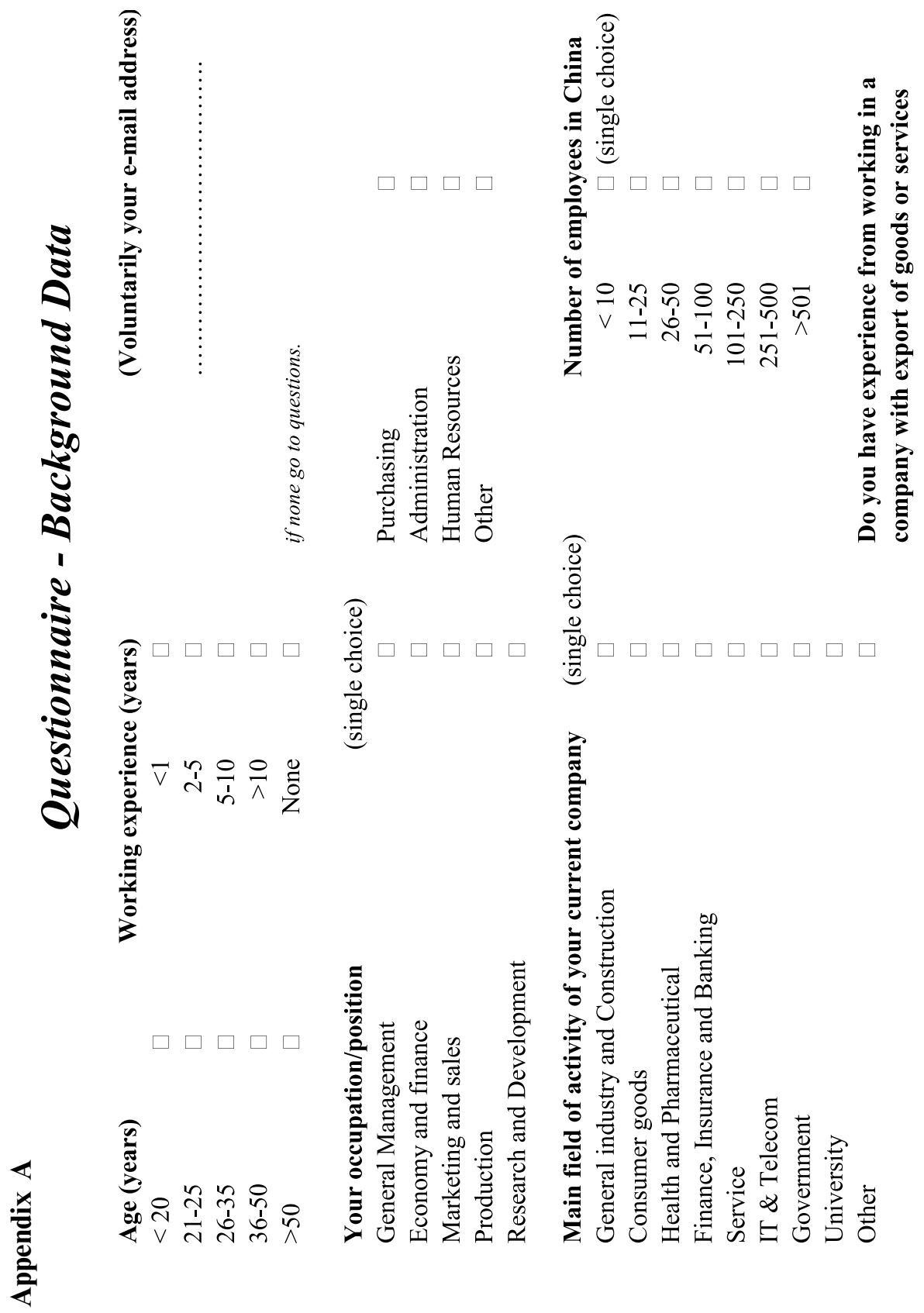



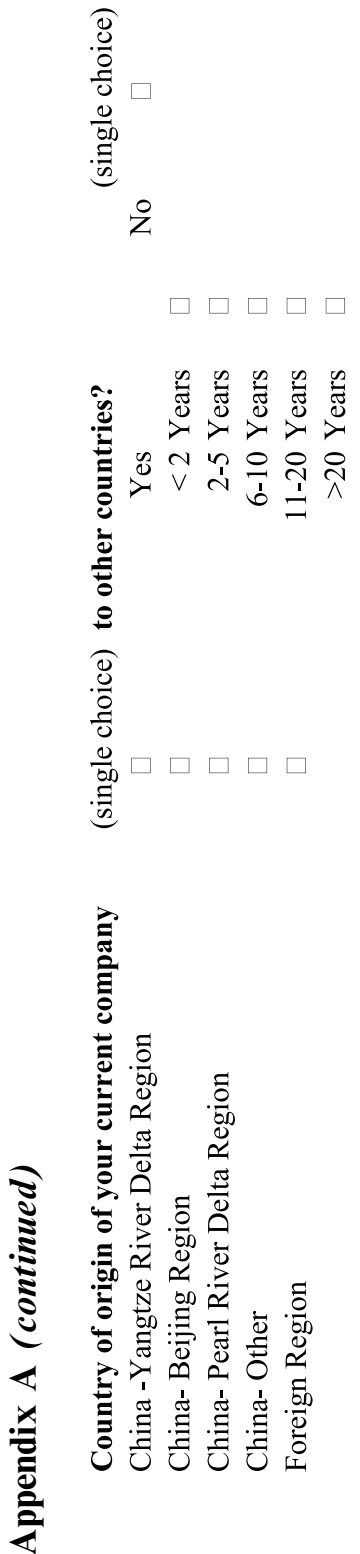

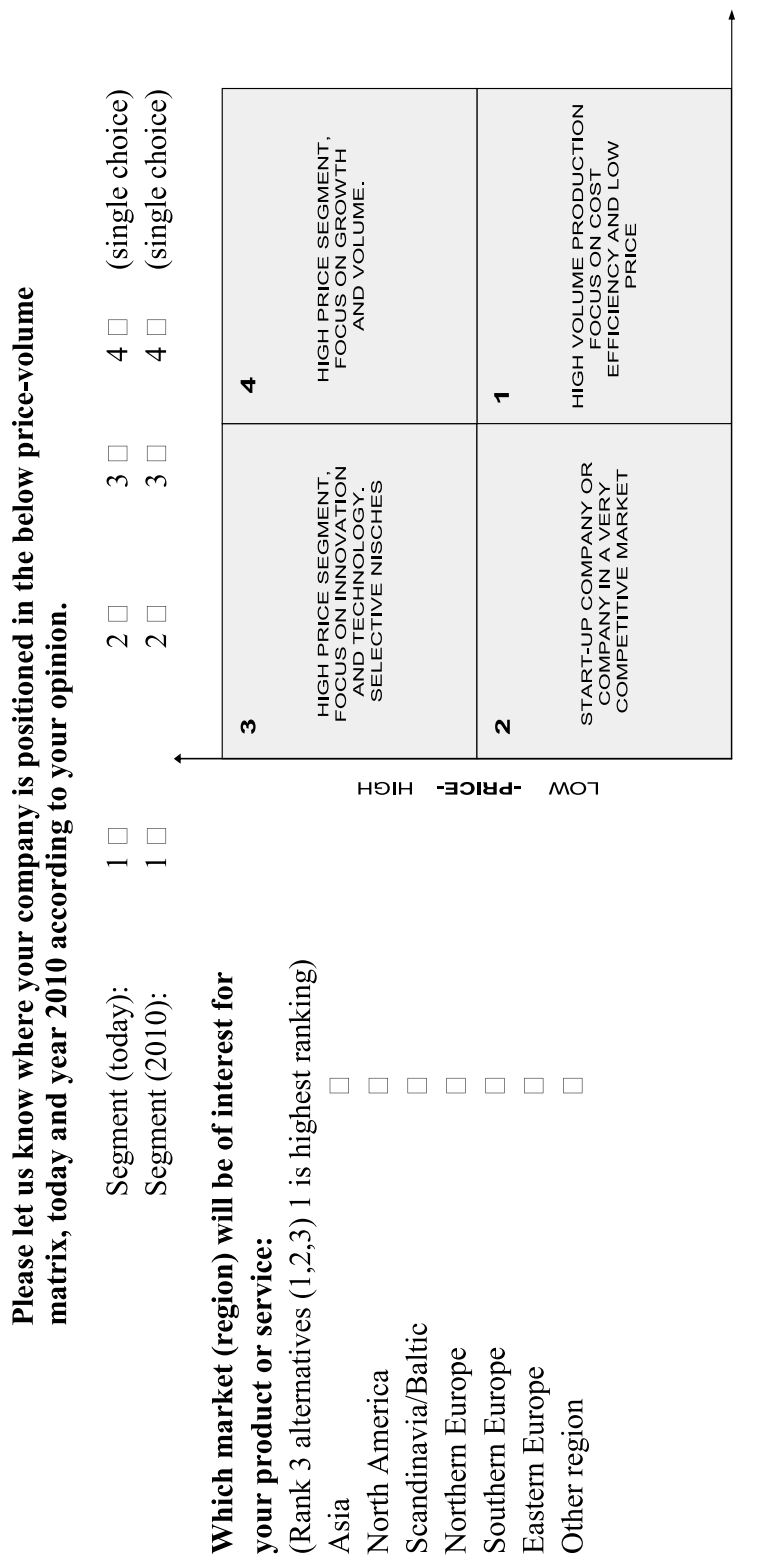




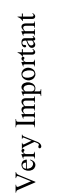

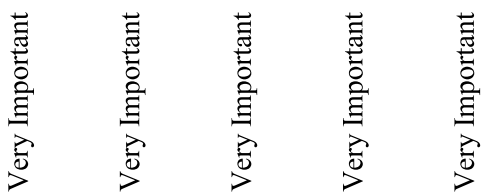

$\square$

$\square$

$\square$

$\square$

$\begin{array}{lll}\square & \square & \square\end{array}$
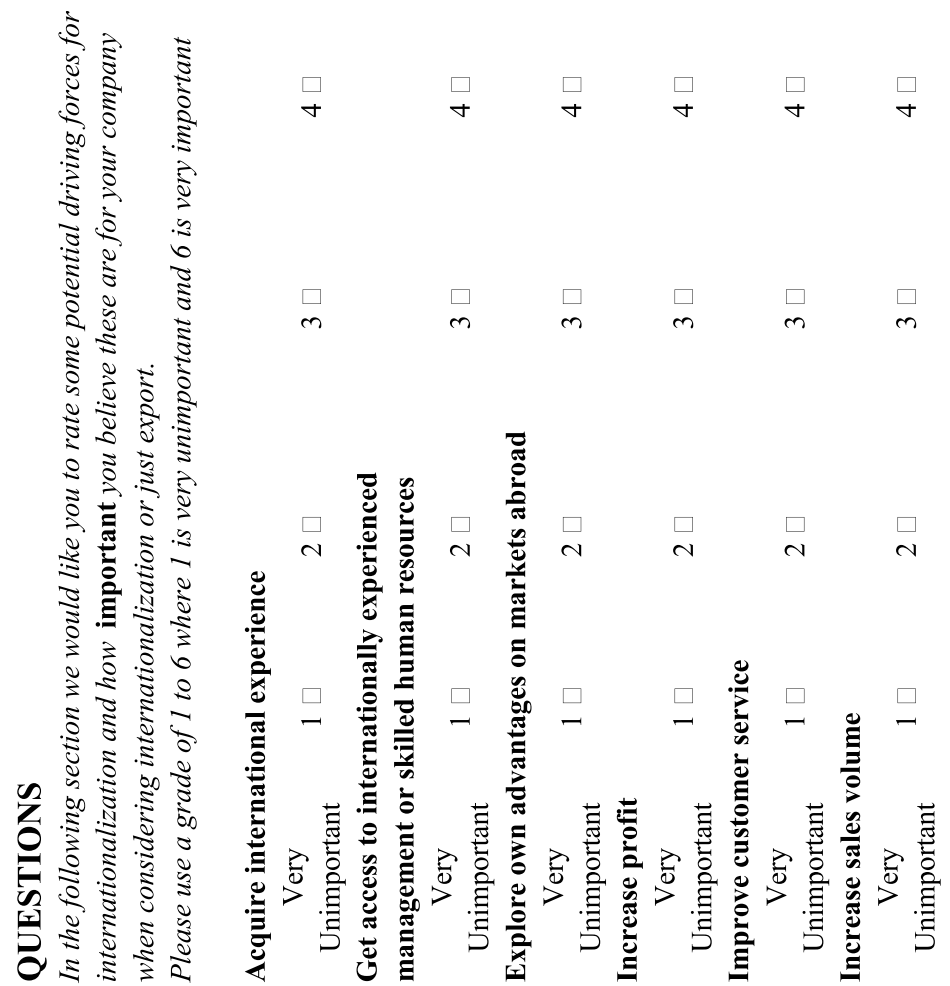


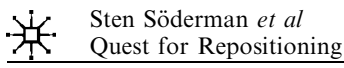

140

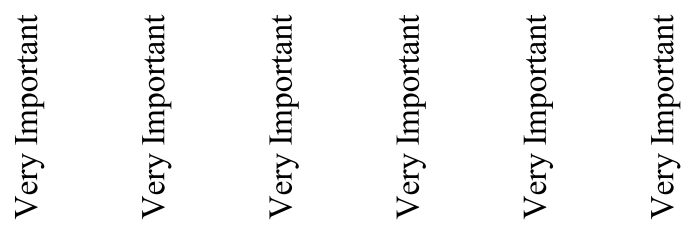

$\begin{array}{llllll}\square & \square & \emptyset & \emptyset & \emptyset & \emptyset\end{array}$

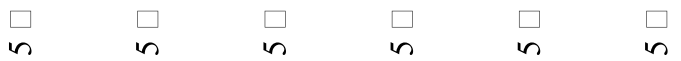

$\begin{array}{llllll}\square & \square & \square & \square & \square & \square\end{array}$

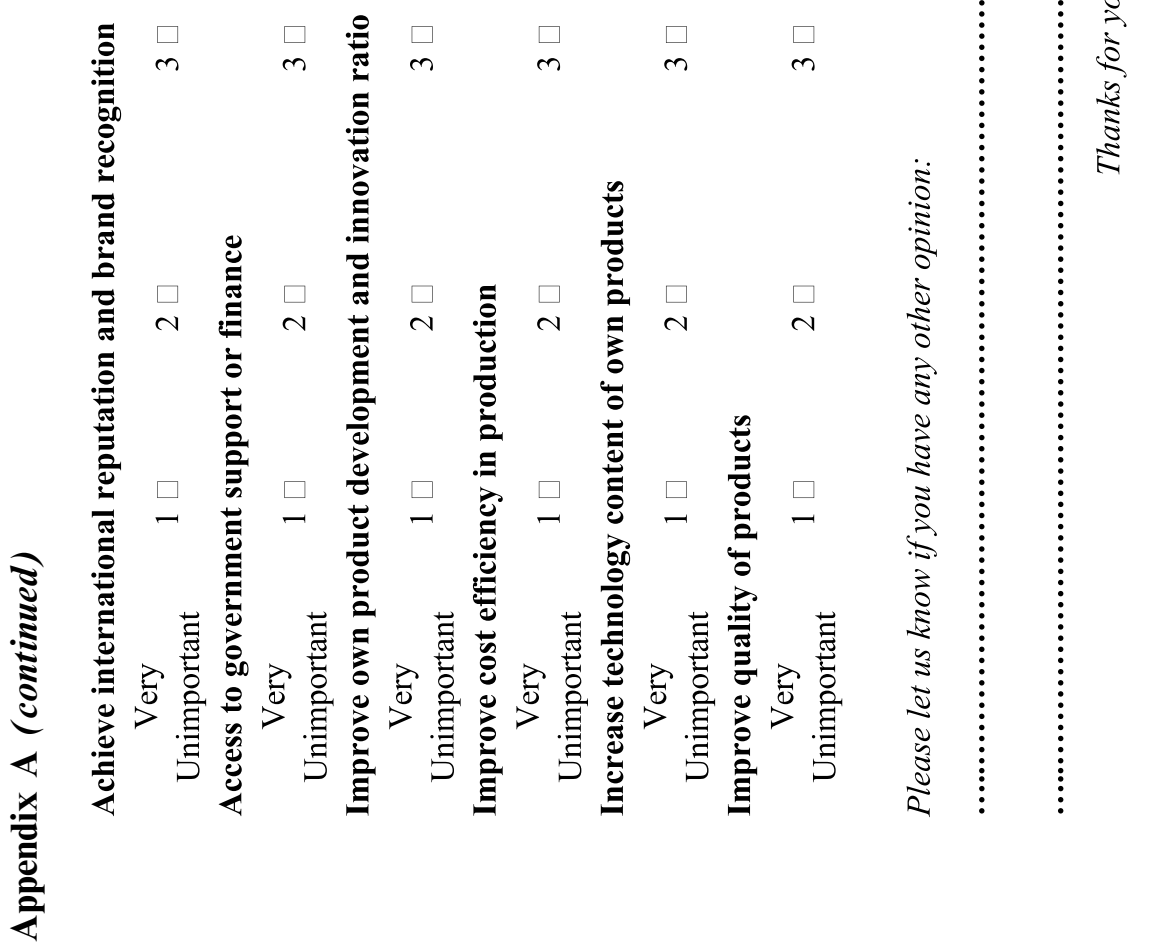

Asian Business \& Management 20087 


\section{Appendix B: Respondents' answers}

\begin{tabular}{|c|c|c|c|}
\hline & Respondent & $\begin{array}{l}\text { Share } \\
(\%)\end{array}$ & $\begin{array}{l}\text { Total } \\
(\%)\end{array}$ \\
\hline \multirow[t]{5}{*}{ Age (years) } & $<20$ & 1.0 & \\
\hline & $21-25$ & 29.4 & \\
\hline & $26-35$ & 63.7 & \\
\hline & $36-50$ & 2.9 & \\
\hline & $>50$ & 2.9 & 100 \\
\hline \multirow[t]{5}{*}{ Working experience (years) } & $<1$ & 10.0 & \\
\hline & $2-5$ & 27.0 & \\
\hline & $5-10$ & 54.0 & \\
\hline & $>10$ & 9.0 & \\
\hline & None & 0.0 & 100 \\
\hline \multirow[t]{9}{*}{ Your occupation/position } & General management & 9.2 & \\
\hline & Economy and finance & 13.8 & \\
\hline & Marketing and sales & 45.0 & \\
\hline & Production & 11.0 & \\
\hline & Research and development & 3.7 & \\
\hline & Purchasing & 1.8 & \\
\hline & Administration & 7.3 & \\
\hline & Human resources & 0.9 & \\
\hline & Other & 7.3 & 100 \\
\hline \multirow[t]{9}{*}{$\begin{array}{l}\text { Main field of activity of your current } \\
\text { company }\end{array}$} & $\begin{array}{l}\text { General industry and } \\
\text { construction }\end{array}$ & 48.0 & \\
\hline & Consumer goods & 11.8 & \\
\hline & Health and pharmaceutical & 2.9 & \\
\hline & Finance, insurance and banking & 6.9 & \\
\hline & Service & 6.9 & \\
\hline & IT and Telecom & 10.8 & \\
\hline & Government & 2.0 & \\
\hline & University & 0.0 & \\
\hline & Other & 10.8 & \\
\hline \multirow[t]{7}{*}{ Number of employees in China } & $<10$ & 7.1 & 100 \\
\hline & $11-25$ & 8.1 & \\
\hline & $26-50$ & 9.1 & \\
\hline & $51-100$ & 11.1 & \\
\hline & $101-250$ & 11.1 & \\
\hline & $251-500$ & 17.2 & \\
\hline & $>500$ & 36.4 & 100 \\
\hline \multirow[t]{5}{*}{ Country of origin of your current company } & $\begin{array}{l}\text { China - Yangtze river delta } \\
\text { region }\end{array}$ & 41.6 & \\
\hline & China - Beijing region & 12.9 & \\
\hline & China - Pearl River delta region & 11.9 & \\
\hline & China - other & 20.8 & \\
\hline & Foreign region & 12.9 & 100 \\
\hline
\end{tabular}


Appendix B: (Continued)

\begin{tabular}{|c|c|c|c|}
\hline & Respondent & $\begin{array}{c}\text { Share } \\
(\%)\end{array}$ & $\begin{array}{c}\text { Total } \\
(\%)\end{array}$ \\
\hline $\begin{array}{l}\text { Do you have experience from } \\
\text { working in } \\
\text { a company } \\
\text { with export of goods or services } \\
\text { to other countries? }\end{array}$ & $\begin{array}{l}<2 \\
2-5 \\
6-10 \\
11-20 \\
>20 \\
\text { No }\end{array}$ & $\begin{array}{r}28.7 \\
14.9 \\
11.9 \\
2.0 \\
1.0 \\
41.6\end{array}$ & 100 \\
\hline $\begin{array}{l}\text { Please let us know where your } \\
\text { company is positioned } \\
\text { in the below price/volume today } \\
\text { and } 2010 \text { matrix, }\end{array}$ & $\begin{array}{l}1 \text { today } \\
2 \text { today } \\
3 \text { today } \\
4 \text { today }\end{array}$ & $\begin{array}{l}58.4 \\
12.9 \\
12.9 \\
15.8\end{array}$ & 100 \\
\hline & $\begin{array}{ll}1 & 2010 \\
2 & 2010 \\
3 & 2010 \\
4 & 2010\end{array}$ & $\begin{array}{r}42.0 \\
4.0 \\
30.0 \\
24.0\end{array}$ & 100 \\
\hline $\begin{array}{l}\text { Which market (region) will be of } \\
\text { interest to your } \\
\text { product or service }\end{array}$ & $\begin{array}{l}\text { Asia } \\
\text { North America } \\
\text { Scandinavia/Baltic } \\
\text { Northern Europe } \\
\text { Southern Europe } \\
\text { Eastern Europe } \\
\text { Other region }\end{array}$ & $\begin{array}{l}85.3 \\
49.0\end{array}$ & \\
\hline
\end{tabular}

